\title{
Floral Resources and Nesting Requirements of the Ground-Nesting Social Bee, Lasioglossum malachurum (Hymenoptera: Halictidae), in a Mediterranean Semiagricultural Landscape
}

\author{
Carlo Polidori, ${ }^{1}$ Alice Rubichi, ${ }^{1}$ Valeria Barbieri, ${ }^{1}$ Luca Trombino, ${ }^{2}$ and Marta Donegana ${ }^{3}$ \\ ${ }^{1}$ Dipartimento di Biologia, Sezione di Zoologia e Citologia, Università degli Studi di Milano, Via Celoria 26, 20133 Milano, Italy \\ ${ }^{2}$ Dipartimento di Scienze della Terra, Università degli Studi di Milano, Via Mangiagalli 34, 20133 Milano, Italy \\ ${ }^{3}$ Laboratorio di Palinologia e Paleoecologia, Istituto per la Dinamica dei Processi Ambiental, Consiglio Nazionale Ricerche, \\ Piazza della Scienza 1, 20126 Milano, Italy
}

Correspondence should be addressed to Carlo Polidori, carlo.polidori@unimi.it

Received 24 July 2009; Accepted 11 December 2009

Academic Editor: Claus Rasmussen

Copyright (c) 2010 Carlo Polidori et al. This is an open access article distributed under the Creative Commons Attribution License, which permits unrestricted use, distribution, and reproduction in any medium, provided the original work is properly cited.

\begin{abstract}
In order to adopt correct conservation strike plans to maintain bee pollination activity it is necessary to know the species' resource utilisation and requirements. We investigated the floral resources and the nesting requirements of the eusocial bee Lasioglossum malachurum Kirby at various sites in a Mediterranean landscape. Analysis of bees' pollen loads showed that Compositae was the more exploited family, although interpopulations differences appeared in the pollen types used. From 5 to 7 pollen types were used by bees, but only as few as 1-1.9 per load. Variations of the pollen spectrum through the annual nesting cycle were conspicuous. At all sites, bees nested in horizontal ground areas with high soil hardness, low acidity, and rare superficial stones. On the other side, the exploited soil was variable in soil granulometry (although always high in $\%$ of silt or sand) and it was moderately variable in content of organic matter and highly variable in vegetation cover. Creation of ground patches with these characteristics in proximity of both cultivated and natural flowering fields may successfully promote colonization of new areas by this bee.
\end{abstract}

\section{Introduction}

Bees (Apoidea) provide pollination of many wild and cultivated plant species $[1,2]$ and important services to agriculture $[3,4]$; however, their biodiversity in crop areas is threatened by increasing agricultural intensification, which includes the loss of natural and seminatural habitats and extensive monoculture plantings [5-7]. Despite the importance of wild bees in crop pollination, farmers, in particular in the Mediterranean area, still underestimate the importance of managing wild bee populations. Wild bees may be very successful in the pollination of crops, in particular some plants rarely exploited by honey bees or in areas affected by strong decline of honey bee populations [8-10]. It is thus necessary to adopt correct conservation management plans in order to maintain bee pollination activity. A first step to build conservation plans for bees, and eventually to evaluate if a given wild bee species may be useful for crop pollination, is to quantify its resource utilisation and requirements [11]. Excluding the honey bee, important data on these aspects are available in particular for bumblebees (Bombus spp.) (e.g., [12-14]), while very little is yet known on other wild bees, both solitary and social (e.g., $[15,16])$. Likewise, we still have little information on which species pollinate crops [17]. Because, at least in part, natural history traits such as sociality and nesting requirements can determine how bees respond to land use $[8,18]$, a good knowledge of resource use (both food and nesting habitat) of wild bee species is necessary to eventually manage successfully populations in agricultural areas.

The aim of this study was to evaluate the pollen resources and the nesting requirements of a common European 
wild bee, the ground-nesting and eusocial Lasioglossum malachurum Kirby (Hymenoptera: Halictidae), in a Mediterranean area in Central Italy. This area is included in a protected reserve (Maremma Regional Park) and contains both extensive crop fields and natural and seminatural areas. Mediterranean ecosystems are still poorly investigated with regard to bee ecology [19-22], and floral preferences are much better known in the bee species of Central Europe and North America (e.g., $[23,24])$. On the other hand, data on physical-chemical features of nesting sites, such as soil granulometry, acidity, and organic matter, are even more poorly known in ground-nesting bees of Mediterranean, despite it is known that nest founding occurs only if substrate posses determined characteristics, which may change among bee genera or species [25-27].

Lasioglossum malachurum is a typical primitively eusocial sweat bee [28]. Queens establish their colonies in subterranean nests in spring and then produce one (in Northern Europe) to three (in Southern Europe) worker phases and a last phase composed of males and gynes; these phases are separated by several days during which no foraging activity takes place [29-31]. Mated gynes (queens) overwinter and found new colonies in the following spring. Workers from different European areas were often observed to visit many different flowers, mainly yellow composites [30]. Despite its abundance in most part of Europe, almost nothing is known on the relative importance of each foraged plant in the diet and on nesting requirements of this species, except anecdotal observations [30, 32].

To evaluate floral resources and nesting requirements of L. malachurum, we studied different populations located in diverse environments, from agricultural areas to urban areas to seminatural woody areas of the Park.

\section{Materials and Methods}

2.1. Study Area and Studied Species. The study area, of about $8 \mathrm{~km}^{2}$, was located near Alberese, a small town inside the Maremma Regional Park (Tuscany, Italy: $42^{\circ} 40^{\prime} 5^{\prime \prime} \mathrm{N}$, $\left.11^{\circ} 6^{\prime} 23^{\prime \prime} \mathrm{E}\right)$. This area is typically Mediterranean, with the average annual temperature around $14-15^{\circ} \mathrm{C}\left(7.1^{\circ} \mathrm{C}\right.$ in January, $23.1^{\circ} \mathrm{C}$ in August); the average yearly rainfall is about $690 \mathrm{~mm}$, with a maximum in November-December and a minimum in July-August. The main part of the park is characterised by the Uccellina mountains, a chain of hills parallel to the coast and covered by the thick Mediterranean maquis. In this area, L. malachurum is commonly found nesting in small $(<50)$ to very large $(>2000)$ nest aggregations in a variety of locations, such as along tracks in the woods, along cultivated fields, or even in small bare soil patches inside the town. Two bee nesting sites were chosen for the study of pollen resources: site A was located in a Quercus wood, while site B was located along an alfalfa field about $100 \mathrm{~m}$ from the Ombrone river. The two sites were separated by about $3 \mathrm{~km}$, and in both L. malachurum nested copiously (>1000 nests at both sites). Other bee or wasp species nested in the same areas, although with a minor abundance [33]. For the study of nesting substrate, we used both sites A and
$B$ and, additionally, 3 other nest aggregations: site $C$ within Alberese town where nests were found in a small area of bare soil (about 20 nests), site D along a tomato field (about 40 nests), and site $\mathrm{E}$ on a pathway bounding a farm (about 100 nests). No less than $1 \mathrm{~km}$ separated these sites.

\subsection{Flowering Plants Richness, Bee Pollen Collection, and Iden-} tification. Pollen loads were collected from bees returning to their nest after a foraging trip, from 15 to 20 April (only at site B), from 15 to 30 May (at sites $A$ and B), from 15 to 30 June (at sites A and B), and from 23 July to 8 August (only at site B) in 2005 (pollen were not sampled daily). Except in April, when queens were still foraging alone, we collected pollen from workers. Considering that this bee species is characterized by 7-25 days-periods of foraging separated by similar length periods of null foraging (activity breaks) during the annual nesting cycle (e.g., [32]), we believe that sampling through 15 days during each foraging phase can give a realistic picture of pollen use. The collections took place between 9.00 and 15.00 in April and May, between 9.00 and 18.00 in June, and between 9.00 and 12.00 in July/August, according to the different daily periods of foraging by the bees in the three periods. Then we associated each pollen sample with one of the three daily periods (9.00-11.59, 12.00-14.59 and 15.00-17.59). Site A was not sampled in April and July/August because only very few females were active in those periods $(<5)$. On the first and the last day of each period we also sampled all the species of flowering pollen-producing plants in a $1 \mathrm{~km}$ radius from the nest aggregation in order to obtain plant taxa richness. This radius was chosen because females of Apoidea generally forage at relatively short distances from the nesting site, rarely more than $1 \mathrm{~km}[34,35]$. Greenleaf et al. [34] recorded a maximum foraging distance for L. malachurum of $600 \mathrm{~m}$.

Once a pollen-carrying bee was collected, it was placed in a $1.5 \mathrm{~mL}$ eppendorf tube and placed in a box for $10-15$ minutes, where, in the dark, they readily downloaded the pollen grains as normally occurs in the brood cells. The bee was then released and the pollen load preserved until the laboratory analysis. From 8 to 20 (average $=14$, standard deviation $=5.4$ ) bee pollen loads were collected per period at each site.

Pollen loads were then prepared in the laboratory for identification. After acetolysis [36], from 1400 to 1800 pollen grains of the pollen load of each forager were observed with a light microscope and classified by morphology into taxonomically distinct pollen types. Identification was based on pollen keys available in the literature on the European flora [37-47], on the pollen collection preserved at the laboratory of palynology CNR-IDPA (Milan), and by comparison with the pollen obtained by the plants sampled by us in the area. Identification reached at least the family level, sometimes the genus-level or type-level (which may includes species of a single genus or of different related genera of a single family).

On the whole, roughly 95000 pollen grains were classified, and relative abundances of pollen types estimated as \%. Those types accounting for less than $1 \%$ were excluded for 
further analysis because they may be contaminations [48]. By preserving individual pollen loads in separate tubes in the field, however, we excluded contamination as much as possible.

\subsection{Soil Sampling and Nesting Substrate Characterization.} From the five nesting aggregations chosen for the study of nesting requirements we recorded directly environmental variables of the nesting site and collected and analysed in laboratory soil samples. This part of the study was done in July 2008. The substrate variables of the field were recorded in 3 plots of $1 \mathrm{~m} \times 1 \mathrm{~m}$ at each nesting site. They were the following: (i) \% of vegetation cover (estimation by eye), (ii) number of stones with diameter $>5 \mathrm{~cm}$, (iii) $\%$ of stone cover (estimation by eye), (iv) slope of soil surface (with an Abney level, to the nearest 0.1 degree), and (v) soil hardness (measured with a penetrometer to the nearest $0.1 \mathrm{Kg} / \mathrm{cm}^{2}$; 3 measures were taken per plot).

Soil samples comprised $500 \mathrm{~g}$ of soil in the upper 10$15 \mathrm{~cm}$; one sample per nesting site was obtained. The samples were then transported to the laboratory in closed plastic bags, weighed to the nearest $0.0001 \mathrm{~g}$, and then opened to obtain the dry sample used for the further analysis.

Once dry, we reweighed the sample and passed it through a $2000 \mu \mathrm{m}$-sieve, suspended in $\mathrm{H}_{2} \mathrm{O}_{2}$ to remove the organic matter, and passed again in sieves of 1400, 1000, 710, 500,

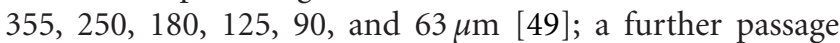
through aerometry was performed on the soil sample which passed the $63 \mu \mathrm{m}$-sieve (clay) [49]. Weighting all the samples from each of the sieves we obtained the data to build granulometric curves, which are based on the cumulative percentage of particles falling in the granulometric classes (expressed as $\varphi$-intervals, where $\varphi=-\log _{2}$ (particle diameter in $\left.\mathrm{mm}\right)$ ). We thus evaluated the relative proportions of gravel, sand, silt, and clay in the soil samples [49].

Organic carbon was quantified following the method described in a technical guide of the Italian Ministry of agriculture, food and forest resources [50] and then converted to organic matter with the equation: organic matter $=$ $1.724^{*}$ organic carbon.

To quantify $\mathrm{pH}$ of the soil we used only the subsample with granulometry $<2000 \mu \mathrm{m}$. Ten g were added $25 \mathrm{~mL}$ of bidistilled water, and the following day the $\mathrm{pH}$ was recorded with a $\mathrm{pH}$ sensor to the nearest 0.1 unit.

Thus, from the analysis of soil, we obtained 6 variables: (i) quantity of organic matter (mg), (ii) $\mathrm{pH}$, (iii) $\%$ of gravel, (iv) $\%$ of sand, (v) $\%$ of silt, and (vi) $\%$ of clay.

2.4. Statistical Analysis. Nonparametric statistics were used to analyse the data. The $\chi^{2}$-test and the $G$-test was used to compare richness and relative abundance (resp.) of pollen families/types in samples across periods; the Yates' continuity correction was applied to these tests in case of $\mathrm{df}=1$. The Spearman correlation test was used to look for linear correlations between sets of data. The Mann-Whitney test and the Kruskall-Wallis test were used to compare medians between two or more samples, respectively. A series of Kolmogorov-Smirnov tests was used to test for differences in distributions of cumulative $\%$ of the $\varphi$-classes in the granulometric curves between sites.

In the text, average numbers are given \pm standard deviation.

\section{Results}

3.1. Pollen Resources. A total of 27 blooming plant families were collected around the nest aggregation at site A and 28 at site B (Table 1). The floral community was slightly different between the two sites, with some families collected exclusively at the wood site (site A) (e.g., Apocynaceae, Boraginaceae) and some other only at the crop site (site B) (e.g., Chenopodiaceae, Verbaniaceae) (Table 1). On the whole, 23 families were collected at both sites, although sometimes represented by different genera (e.g., about half of the genera of Compositae were collected at both sites) and much more often by different species (on the whole, 67 species were sampled at the wood site and 56 at the crop site, but only 17 species were present at both sites).

L. malachurum workers foraged for pollen on plants belonging to 4 families at site A and 6 at site B; however, the resource exploitation, in terms of the number of families used out of the number of available families, was not less at the wood site $(14.3 \%)$ than at the wood site $(20.7 \%)$ ( $G$-test, $G=0.082, \mathrm{df}=1, P>.05)$. The number of families used relative to their number in the environment changed slightly through the period of collection at both sites (Figures 1(a) and 1(b)). At the wood site, richness in plant families did not change significantly from May to June $\left(\chi^{2}-\right.$ test, $\chi^{2}=2.31$, df $=1, P>.05$ ) (Figure 1(a)). Richness in plant families in the environment at the crop site also did not change significantly from April to July/August $\left(\chi^{2}\right.$-test, $\left.\mathrm{df}=3, \chi^{2}=3.10, P>.05\right)$. The number of plant families used by bees seems to follow the same slight trends across the season: at the wood site, it decreased from May to June (Figure 1(a)), while at the crop site it reached the maximum in June and the minimum in April, decreasing in July/August (Figure 1(b)). As a result, there was a marginally significant correlation between plant richness in the environment and that used by bees (using all the periods/sites) (Spearman correlation test, $r=0.74, n=6, P=.046)$.

With the exception of Rosaceae (which were exploited at site B only in June despite they were still flowering in July/August) and Cruciferae (which were used at site B in May but not in April despite already flowering in that month), bees at both sites did not seem to change plant families until their pollen source is no longer available. However, the relative use of these plant families conspicuously changed across periods.

In fact, Compositae (34.4\%) and Euphorbiaceae (38.3\%) were, on the whole, the most abundant families represented in pollen loads at the wood site (followed by Cistaceae $(21.4 \%)$ and Papaveraceae $(5.5 \%))$, but not in all the periods: Compositae was almost the only family used in June ( $G$-test, $G=3433, \mathrm{df}=1, P<.0001)$, while Euphorbiaceae was the most used family in May ( $G$-test, $G=1672.4 \mathrm{df}=3$, $P<.0001$ ) (Figure 1(a)). By contrast, Compositae was by far the most used family at the crop site $(80.3 \%)$, followed 
TABLE 1: List of families and genera collected in the environment around L. malachurum nesting sites, and relative use of plant genera/pollen types (richness of used taxon/richness in the environment* 100) in the families where genera/type-level identification of pollen from bees was possible. Genera/types in bold were found in bee pollen loads. Only taxa represented in pollen loads by more than $1 \%$ were considered.

\begin{tabular}{|c|c|c|c|c|c|c|c|c|}
\hline $\begin{array}{l}\text { Site } \\
\text { A }\end{array}$ & $\begin{array}{l}\text { Site } \\
\text { B }\end{array}$ & Plant family & $\begin{array}{c}\text { Collected } \\
\text { by bees at } \\
\text { site A }\end{array}$ & $\begin{array}{c}\text { Collected } \\
\text { by bees at } \\
\text { site B }\end{array}$ & $\begin{array}{l}\text { Plant genera in the } \\
\text { environment at site A }\end{array}$ & $\begin{array}{l}\text { Plant genera in the } \\
\text { environment at site B }\end{array}$ & $\begin{array}{c}\text { Use by } \\
\text { bees at } \\
\text { site A }\end{array}$ & $\begin{array}{c}\text { Use by } \\
\text { bees at } \\
\text { site B }\end{array}$ \\
\hline $\mathrm{X}$ & - & Apocynaceae & no & no & Vinca & - & - & - \\
\hline $\mathrm{X}$ & - & Aristolochiaceae & no & no & Aristolochia & - & - & - \\
\hline $\mathrm{X}$ & - & Boraginaceae & no & no & Echium, Myosotis & - & - & - \\
\hline $\mathrm{X}$ & - & Campanulaceae & no & no & Campanula & - & - & - \\
\hline $\mathrm{X}$ & $\mathrm{X}$ & Caryophyllaceae & no & yes & $\begin{array}{l}\text { Petrorhagia, Silene, } \\
\text { Stellaria }\end{array}$ & - & - & - \\
\hline - & $\mathrm{X}$ & Chenopodiaceae & no & yes & - & not determined & - & - \\
\hline $\mathrm{X}$ & $\mathrm{X}$ & Cistaceae & yes & yes & Cistus, Helianthenum & Cistus & $50 \%$ & - \\
\hline $\mathrm{X}$ & $\mathrm{X}$ & Compositae & yes & yes & $\begin{array}{l}\text { Anthemis, Bellis, } \\
\text { Chicorium, Cirsum, } \\
\text { Coleostephus, Crepis, Evax, } \\
\text { Filago, Hieracium, Inula, } \\
\text { Pallenis }\end{array}$ & $\begin{array}{l}\text { Anthemis, Bellis, } \\
\text { Centaurea, Hieracium, } \\
\text { Pallenis, Picris, Doronico, } \\
\text { Aster, Senecio, Sonchus }\end{array}$ & $18.2 \%$ & $50 \%$ \\
\hline $\mathrm{X}$ & $\mathrm{X}$ & Convolvulaceae & no & yes & Convolvulus & Convolvulus, Calystegia & - & $50 \%$ \\
\hline $\mathrm{X}$ & $\mathrm{X}$ & Cruciferae & yes & yes & $\begin{array}{l}\text { Arabis, Capsella, } \\
\text { Rapistrum, Sysimbrium }\end{array}$ & Arabis, Brassica, Capsella & - & - \\
\hline $\mathrm{X}$ & $\mathrm{X}$ & Dipsacaceae & no & yes & Knantia & Scabiosa & - & - \\
\hline $\mathrm{X}$ & $\mathrm{X}$ & Euphorbiaceae & yes & yes & Euphorbia & Euphorbia & $100 \%$ & - \\
\hline - & $\mathrm{X}$ & Fagaceae & no & yes & - & Quercus & - & - \\
\hline $\mathrm{X}$ & $\mathrm{X}$ & Geraniaceae & no & no & Geranium & Geranium & - & - \\
\hline $\mathrm{X}$ & $\mathrm{X}$ & Graminaceae & yes & yes & Alopecurus & not determined & - & - \\
\hline $\mathrm{X}$ & $\mathrm{X}$ & Guttiferae & no & yes & Hypericum & Hypericum & - & - \\
\hline $\mathrm{X}$ & $\mathrm{X}$ & Labiatae & no & no & Lamium, Marrubium & Mentha, Stachys & - & - \\
\hline $\mathrm{X}$ & $\mathrm{X}$ & Leguminosae & no & yes & $\begin{array}{l}\text { Lathyrus, Spartium, } \\
\text { Trifolium, Vicia }\end{array}$ & $\begin{array}{l}\text { Medicago, Ononis, } \\
\text { Scorpiurus, Trifolium, Vicia }\end{array}$ & - & - \\
\hline $\mathrm{X}$ & $\mathrm{X}$ & Liliaceae & no & yes & Allium & Ornithogalum & - & - \\
\hline $\mathrm{X}$ & $\mathrm{X}$ & Malvaceae & no & no & Malva & Malva & - & - \\
\hline $\mathrm{X}$ & $\mathrm{X}$ & Papaveraceae & yes & yes & Papaver & Papaver, Fumaria & $100 \%$ & - \\
\hline $\mathrm{X}$ & $\mathrm{X}$ & Pinaceae & yes & yes & Pinus & Pinus & - & - \\
\hline $\mathrm{X}$ & $\mathrm{X}$ & Plantaginaceae & no & yes & Plantago & Plantago & - & - \\
\hline - & $\mathrm{X}$ & Polygonaceae & no & yes & - & Polygonum & - & $100 \%$ \\
\hline $\mathrm{X}$ & $\mathrm{X}$ & Primulaceae & no & no & Anagallis & Anagallis & - & - \\
\hline $\mathrm{X}$ & $\mathrm{X}$ & Ranunculaceae & no & yes & Anemone, Clematis & $\begin{array}{l}\text { Anemone, Clematis, Migella, } \\
\text { Ranunculus }\end{array}$ & - & - \\
\hline $\mathrm{X}$ & $\mathrm{X}$ & Rhamnaceae & no & yes & Paliurus & Rhamnus & - & - \\
\hline $\mathrm{X}$ & $\mathrm{X}$ & Rosaceae & yes & yes & Prunus, Rosa, Sanguisorbia & Rosa & - & - \\
\hline $\mathrm{X}$ & $\mathrm{X}$ & Rubiaceae & no & no & Galium & Galium & - & - \\
\hline - & $\mathrm{X}$ & Scrophulariaceae & no & no & - & Veronica & - & - \\
\hline $\mathrm{X}$ & $\mathrm{X}$ & Umbelliferae & no & yes & $\begin{array}{l}\text { Daucus, Pimpinella, } \\
\text { Ridolfia }\end{array}$ & Daucus, Peucedanum & - & - \\
\hline- & $\mathrm{X}$ & Verbanaceae & no & yes & - & Verbena & - & - \\
\hline
\end{tabular}




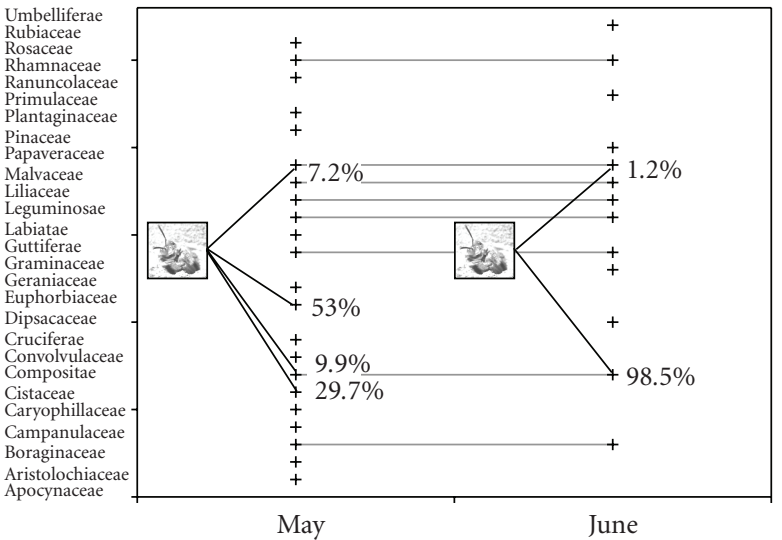

(a)

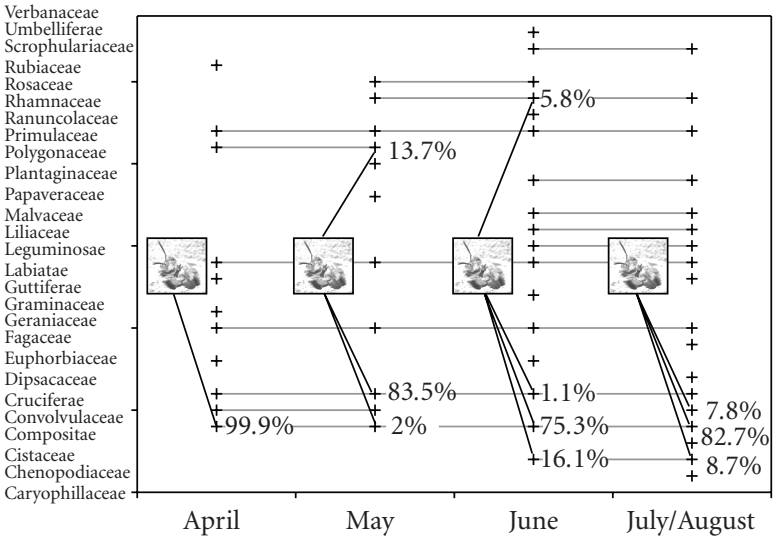

(b)

Figure 1: Presence/absence of plant families sampled in the environment and in bee pollen loads (with associated the relative abundance) (indicated by a line to a bee picture) through the period of collection. (a) Site A (wood site). (b) Site B (crop site). For bees, only families with abundance $>1 \%$ were considered.

by Chenopodiaceae $(8.1 \%)$, Convolvulaceae $(6.8 \%)$, and Cruficerae (3.3\%). Compositae was the only family used in April, and the most used family in June ( $G$-test, $G=6780.4$, $\mathrm{df}=3, P<.0001)$ and July/August $(G$-test, $G=69417.6$, $\mathrm{df}=2, P<.0001)$, while Cruciferae was the most used family in May ( $G$-test, $G=6104.6, \mathrm{df}=2, P<.0001$ ) (Figure $1(\mathrm{~b})$ ).

At a daily level, differences resulted in the relative abundance of pollen plant families used by bees in the morning (9.00-11.59), midday (12.00-14.59), and afternoon (15.00-17.59). In particular, half of the families were mostly collected in the morning and half at midday at site A, while 4 families were mostly collected in the morning and 2 at midday at site B (Table 2).

Considering the pollen collected at genus or type-level, we noted that $L$. malachurum workers foraged for pollen on plants belonging to 5 genera/types at the wood site and 7 pollen genera/types at the crop site. Resource exploitation, in terms of number of genera used out of the number of available genera (in the exploited families), varied from $18.1 \%$ in the Compositae to $50 \%$ in Cistaceae at wood site

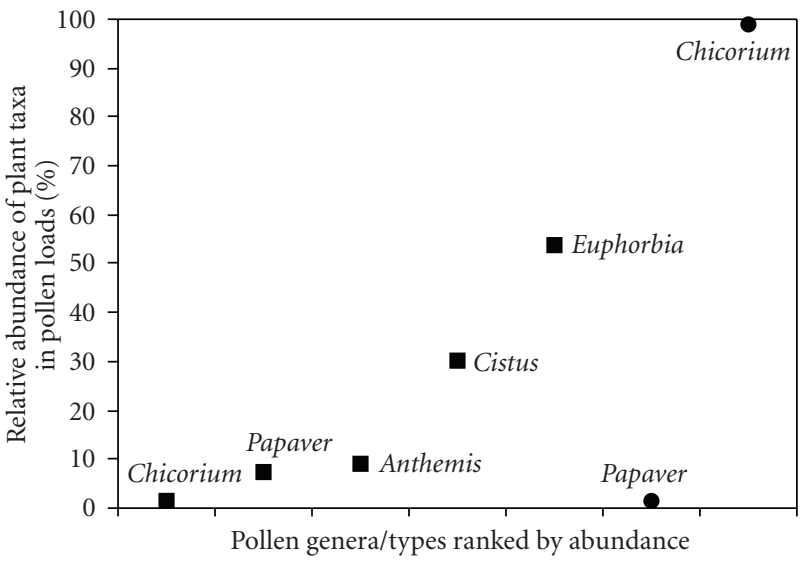

(a)

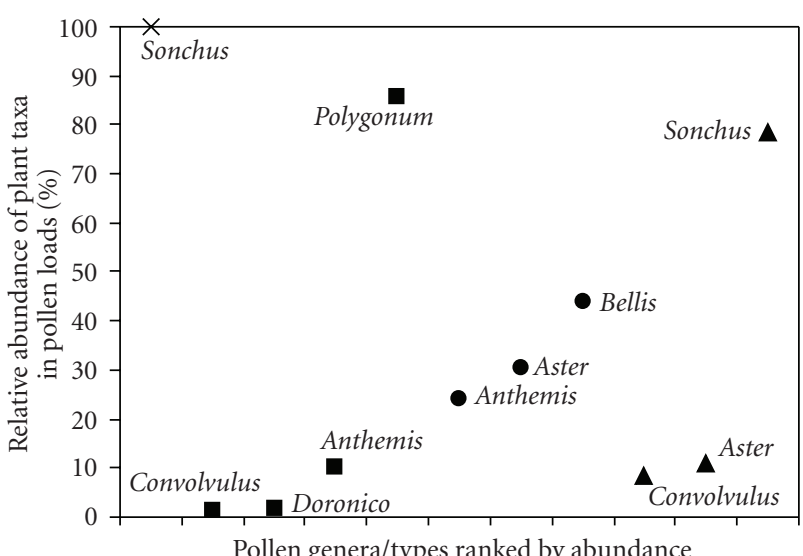

(b)

FIGURE 2: Relative abundance (\%) of different pollen genera/types sampled in bee pollen loads through the period of collection. Marking symbols identify periods: $\times=$ April, $\mathbf{\square}=$ May, $\mathbf{0}=$ June, $\boldsymbol{\Delta}=$ July/August. (a) Site A (wood site). (b) Site B (crop site). Only taxa with abundance $>1 \%$ were considered.

and it was 50\% in Compositae and Convolvulaceae at crop site (Table 1). In case of families represented by one single genus in the environment and used by the bees the overlap was obviously complete (Table 1 ).

Pollen from Chicorium (Compositae) was almost the only sort used in June at wood site ( $G$-test, $G=3424.2$, $\mathrm{df}=1, P<.0001$ ), while Euphorbia (Euphorbiaceae) predominated in May at this site ( $G$-test, $G=4233.3$, $\mathrm{df}=4, P<.0001)($ Figure 2(a)); on the other hand, bees foraged only on Sonchus (Compositae) in April and mostly on this genus in July/August at the crop site ( $G$-test, $G=$ 43368.9, $\mathrm{df}=2, P<.0001$ ), while Polygonum (Polygonaceae) predominated in May ( $G$-test, $G=490.7, \mathrm{df}=3, P<.0001$ ) and a mixture of Bellis, Aster an Anthemis (Compositae), with significant differences in their proportions, predominated in June at this site ( $G$-test, $G=195.8, \mathrm{df}=2$, $P<.0001$ ) (Figure 2(b)). Note that pollens from Cruciferae were not determined at the genus/type level, so that although Polygonum was an abundant genus, it was less abundant than Cruciferae. 
TABLE 2: Relative abundance of pollen plant families collected by bees in three periods of the day. Only families with abundance $>1 \%$ were considered.

\begin{tabular}{|c|c|c|c|c|c|}
\hline Site & Family & $9.00-11.59$ & $12.00-14.59$ & $15.00-17.59$ & $G$-test $(\mathrm{df}=2)$ \\
\hline A & Cistaceae & 75.1 & 16.0 & 8.9 & $G=1292.2, P<.0001$ \\
\hline A & Compositae & 70.2 & 20.5 & 9.3 & $G=1650.6, P<.0001$ \\
\hline A & Euphorbiaceae & 38.7 & 47.3 & 13.9 & $G=555.2, P<.0001$ \\
\hline A & Papaveraceae & 5.8 & 68.8 & 25.4 & $G=272.9, P<.0001$ \\
\hline B & Chenopodiaceae & 92.2 & 2.4 & 5.4 & $G=19356.9, P<.0001$ \\
\hline B & Compositae & 91.0 & 8.2 & 0.8 & $G=184939, P<.0001$ \\
\hline B & Convolvulaceae & 100.0 & 0.0 & 0.0 & - \\
\hline B & Cruciferae & 55.6 & 44.4 & 0.0 & $G=3222.9, P<.0001$ \\
\hline B & Polygonaceae & 39.8 & 60.2 & 0.0 & $G=35.4, P<.0001$ \\
\hline B & Rosaceae & 7.1 & 90.1 & 2.8 & $G=502.1, P<.0001$ \\
\hline
\end{tabular}

TABLE 3: Superficial characteristics of the nesting sites of L. malachurum sampled in 2008. Measures were taken at 3 plots of $1 \mathrm{~m} \times 1 \mathrm{~m}$ at each site. Except for soil hardness, which was taken 3 times at each plot ( 9 measures per site), all the other variables have $n=3$, so that statistical comparisons were not possible.

\begin{tabular}{|c|c|c|c|c|c|}
\hline Sample code & $\begin{array}{l}\text { Soil hardness } \\
\left(\mathrm{Kg} / \mathrm{cm}^{2}\right)\end{array}$ & Vegetation cover $(\%)$ & $\begin{array}{c}\text { Soil surface } \\
\text { slope (degrees) }\end{array}$ & $\begin{array}{l}\text { Number of stones } \\
\text { with diameter } \\
>5 \mathrm{~cm}\end{array}$ & Stone cover $(\%)$ \\
\hline A & $7.9 \pm 2.1$ & $2.7 \pm 2.5$ & $13.3 \pm 20$ & $3.3 \pm 0.6$ & $13.3 \pm 7.6$ \\
\hline B & $8.6 \pm 1.2$ & 0 & 0 & 0 & 0 \\
\hline $\mathrm{C}$ & $10.7 \pm 0.3$ & $11.7 \pm 16.1$ & 0 & $2.7 \pm 3.8$ & $10.0 \pm 0.0$ \\
\hline $\mathrm{D}$ & $10.9 \pm 0.2$ & $63.3 \pm 5.8$ & 0 & 0 & $1.7 \pm 2.9$ \\
\hline E & $6.5 \pm 1.8$ & $1.7 \pm 2.9$ & 0 & 0 & 2 \\
\hline Statistics & $\begin{array}{l}\text { Kruskall-Wallis test: } \\
\chi^{2}=29.12, P<.001\end{array}$ & - & - & - & - \\
\hline
\end{tabular}

The average number of pollen genera/types per load did not vary through periods at wood site: it was $1.5 \pm 0.7$ in May (median: 1), and 1.2 \pm 0.4 in June (median: 1) (MannWhitney test: $U=246, n_{1}=20, n_{2}=16, P=.12$ ); on the contrary, it changed across periods at the crop site, being $1 \pm 0$ in April (median: 1), $1.9 \pm 0.8$ in May (median: 2), $1.3 \pm 0.4$ in June (median: 1 ) and $1.2 \pm 0.4$ in July/August (median: 1 ) (Kruskall-Wallis test: $\chi^{2}=23.42, \mathrm{df}=3, P<.001$ ). However, one must consider that such difference is due only to the median value for May, which is the double of those of all the other periods.

3.2. Nesting Requirements. The typical nesting site of $L$. malachurum in Maremma Regional Park consisted almost invariably of a horizontal ground area with moderately high to very high soil hardness, which differed between sites, and little stone coverage (Table 3); by contrast, nest aggregations may be covered or not by vegetation (Table 3 ). Soil characteristics varied among sites: some presented high percentages of sand and other high percentages of silt; gravel and clay percentages were in general low, except at one site each where they were moderate (Table 4 ). As a consequence, in some cases granulometric curves (Figure 3) did not differ between sites (site A versus site D, site B versus site E, site C versus site $\mathrm{D}$, and site $\mathrm{C}$ versus site $\mathrm{A}$ : Kolmogorov-Smirnov test, $0.17<D<0.21, n_{1}=n_{2}=28, P>.05$ ), while in all the remaining cases the differences in the results of comparisons of the granulometric curves between sites were significant (Kolmogorov-Smirnov test: $0.35<D<0.49, n_{1}=n_{2}=28$, $P<.05)$.

Amount of organic matter also varied from low to moderate (Table 4). The value of $\mathrm{pH}$ was, on the contrary, quite constant (between 7.4 and 7.8) (weakly alkaline soils) (Table 4).

\section{Discussion}

Lasioglossum malachurum was defined in the past as a polylectic species, being recorded on a variety of flowers, mainly yellow composites [29]. In our study, the conspicuous variation of pollen types sampled from the bee loads across the nesting cycle supports the opportunism of this species. However, it is interesting that our studied populations showed, at least during short periods, a quite narrow pollen spectrum. In fact, in any given period of collection, only a small portion of the available flowering plants present in the environment were actually found in the bee pollen loads. Observing bee foraging at flowers rather than analysing pollen quantitatively, Knerer [29] observed similar situations for this species. In fact, he found that Bellis supplied exclusively the food source of queens in southern England, while Andryala and Plantago were the almost exclusive plants foraged by workers in Spain and in Camargue, respectively. 
TABLE 4: Physical-chemical and granulometry characteristics of the soils sampled in 2008 at nesting sites of L. malachurum.

\begin{tabular}{lcccccc}
\hline Sample code & Organic matter $(\mathrm{mg})$ & $\mathrm{pH}$ & \% gravel & \% sand & \% silt & \% clay \\
\hline A & 12.5 & 7.7 & 14.6 & 26.4 & 31.9 & 27.1 \\
B & 11.7 & 7.4 & 3.0 & 12.5 & 62.7 & 21.8 \\
C & 6.5 & 7.8 & 25.7 & 33.3 & 25.8 & 15.2 \\
D & 17.5 & 7.5 & 13.9 & 40.6 & 28.9 & 16.5 \\
E & 48.2 & 7.5 & 4.0 & 10.0 & 45.6 & 40.4 \\
\hline
\end{tabular}

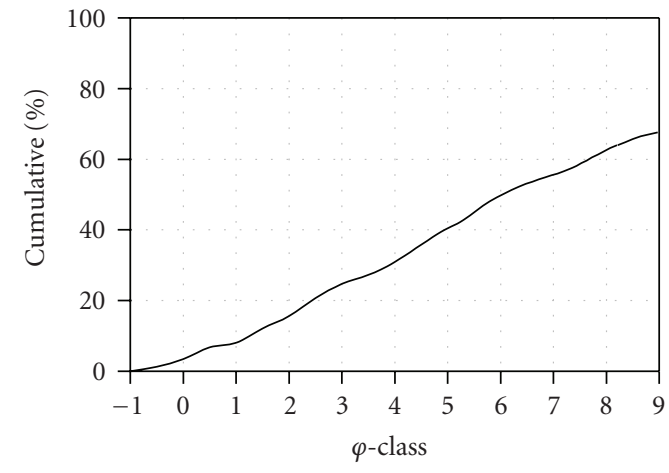

(a)

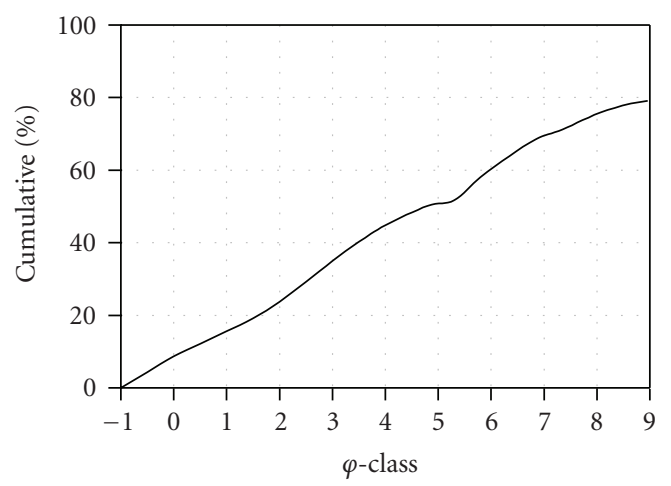

(c)

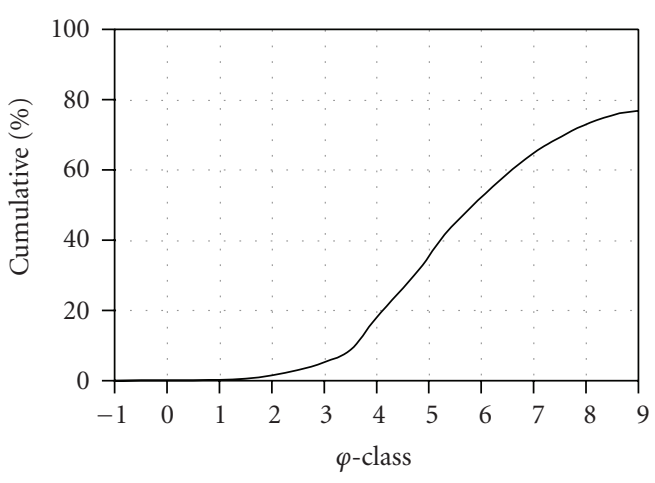

(b)

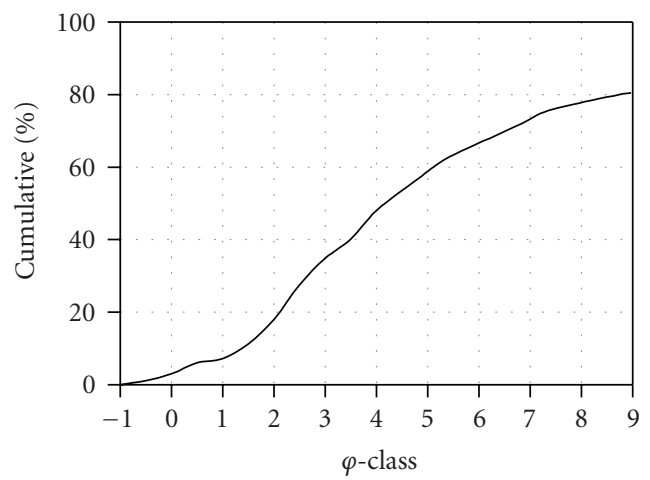

(d)

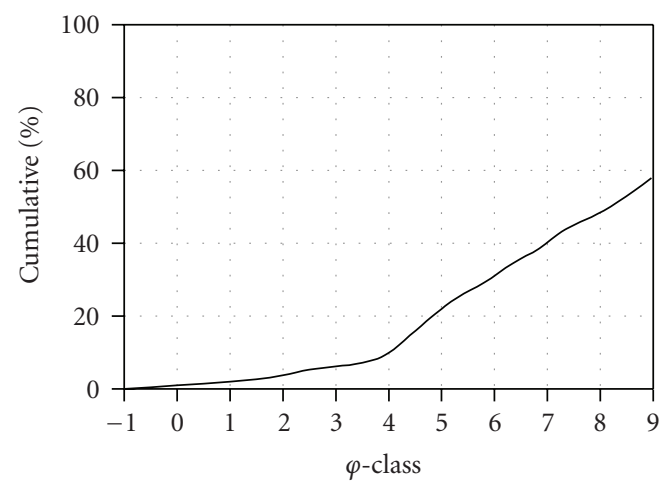

(e)

FIGURE 3: Cumulative frequency curves of soil particles sizes from 5 nesting sites of L. malachurum. On the $x$-axes there are represented the values expressed as $\varphi$-units $\left(-\log _{2}\right.$ of the diameter of the particles, in $\left.\mathrm{mm}\right)$ and on the $y$-axes the cumulative percentages of the particles representing the different granulometric classes. (a)-(e): sites A-E. 
Other halictid bees seem to be much more broadly polylectic than L. malachurum. For example, pollen of 42 plant species from 17 families has been found in the food stores of the halictid bee Halictus subauratus (Rossi), with $61 \%-86 \%$ of the pollen being accounted for by the Compositae [51]. However, also in that case the foragers are characterized by strict flower preferences: more than $90 \%$ of the pollen in each cell belongs to two or three, sometimes four, plant species [51]. Other case studies support the fact that, even in polylectic halictids, the females often collect most food from a small number of plant species. Seladonia confusa (Smith) foragers regularly visit only a few plant species, although they have been observed on the flowers of 165 species [52], and Lasioglossum imitatus (Smith) collects pollen from only one plant species during one flight, although this species was recorded on different plant species [53]. Floral constancy, that is, the tendency to return several times to the same plant species when the pollen is abundantly available, may account for this difference, in these and in other bee species $[54,55]$.

Another factor which probably accounts for differences found among the number of visited plant species and the number of actual pollen types recorded in bee loads or in bee nests is the differential use of flowering plants for nectar and pollen exploitation, with most of plant species visited often only for nectar [56]. We found in bee pollen loads a total of 8 pollen types at wood site and 21 types at crop site, but only 5 and 7 had abundances greater than $1 \%$, suggesting that maybe some pollen grains may attach to the bee body during nectar feeding on nonpollen exploited plants.

Compositae remains probably the most abundant family exploited by polylectic Lasioglossum spp. (e.g., [16, 57]). Data available in literature on pollen load composition of species of the genus showed that the number of pollen types varies broadly: L. villosum Kirby collects pollen of one single type and L. pauxillum Schenck of only 2 kinds, L. morio (Fabricius), L. fulvicorne (Kirby), and L. albipes (Fabricius) use between 7 and 13 pollen types, while both L. leucozonium and L. calceatum use 17 and 23 pollen types, respectively [16]. L. malachurum in our study collected 11 pollen types (populations combined), which results in this species to be moderately polylectic. According to Michener [57], the long season of activity of social bees compared to solitary ones must usually be associated with dependence on a diversity of lowers. L. calceatum and L. malachurum are both eusocial species and have a broad pollen spectrum, but L. pauxillum (eusocial and oligolectic) and L. leucozonium (solitary and polylectic) are evident exceptions to this rule.

On the other side, a lower variance appears in the average number of pollen types per load in Lasiogossum species: in the literature values reported range from 1 to 2 [16], exactly as in our study. This suggests once more the possibility that these bees exploit repeatedly a narrow spectrum of profitable flowering species and that maybe they change their preference only when plant community structure changes. Previous qualitative observations on the pollen load of $L$. malachurum already suggested this possibility: Knerer [29] reported different bees returning to the nests with pollen of specific colours. Our quantitative data even more suggest floral constancy in L. malachurum.

The recorded variation in our study of the pollen preference through the nesting period of the bee suggests the possibility of using L. malachurum to increase pollination of those target plants normally present in the diet of the bee and most preferred in certain periods of the year. For example, L. malachurum foraged quite exclusively for chicory (Chicorium) at the wood site during June and about half of the pollen collected in June at the crop site was of daisy (Bellis). The only two species of these genera sampled in the environment were $C$. intybus $\mathrm{L}$. and B. perennis L., which are commonly cultivated and used by humans as food (the former) or for pharmaceutical infusions (the latter). Moreover, in May at the crop site, bees foraged predominantly on Cruciferae; although it was not possible to determine the pollen type, our environmental survey showed Brassica oleracea L. cultivars (cabbage, broccoli, seed rape) to be cultivated in the farms around the nesting site, and it could be pollinated by L. malachurum. In fact, Brassica crops were importantly visited by other Lasioglossum spp. (e.g., [58]). However, since two other Cruciferae were sampled in the area, Arabis glabra Bernch. and Capsella bursa-pastoris (L.) Medicus, this hypothesis should be explicitly tested with new data.

Other abundant pollen types recorded in bee loads do not seem to be of economical importance but of course may preserve the pollination system and thus the environmental service $[4,7]$.

The quantitative data presented on the nesting site and soil used for nesting of L. malachurum, here reported for the first time for this species, revealed that probably founding queens need horizontal ground surfaces with low stone coverage, hard-packed, and alkaline soils to initiate nest construction, while other factors, such as vegetation cover, seem to be less important. Compact soil and variable presence of spots of vegetation were recorded qualitatively in other nest aggregations of this species $[29,32]$. Other halictid bees seem to respond differently from $L$. malachurum concerning the recorded variables. Across sites, Halictus rubicundus (Christ) prefers softer soils (but not within dense aggregations), sloped ground surfaces, and soils with low to moderate \% of gravel [27]. Potts and Willmer [27] suggested that in dense aggregations females are forced to use hard soils to maintain structural integrity of the nests; however, despite we could not statistically test it, this hypothesis does not seem to work for L. malachurum: in fact, no differences seem to exist between the soil hardness of the smallest (site C) and the largest (site A and B) nesting aggregations, and in any case at least the site $\mathrm{C}$ would be the one with a slightly harder soil. A solitary species, Dieunomia triangulifera (Vachal), prefers areas that avoid vegetation, maybe because vegetation perches could increase the presence of parasitic flies (Conopidae) [26]. In our studied population, no parasitic flies attack L. malachurum with the exception of Megaselia leucozona Schmitz (Diptera: Phoridae), which does not wait for the host on perching sites [59]. 
Soils of other species of Lasioglossum were analysed by Cane [25], and all showed major levels of silt (L. sisymbrii Cockerell, L. laevissimus Smith: from $44 \%$ to $53.8 \%$ ) or sand (L. cinctipes (Provancher): $54.8 \%$ ) but no gravel and low \% of clay thus on the whole similar proportions found in our study on L. malachurum, possibly suggesting a recognizable pattern in nesting habits for the whole genus. It is likely that only some parts of a particular area meet all the apparent criteria necessary for nest initiation, and this may account for aggregation patterns at a landscape level.

Ground-nesting bee species may be more threatened than those that utilise the cavities of wood or plant stems, particularly where intensive agriculture has resulted in loss of nesting habitat as well as floral diversity [60]. However, it was suggested that arable farmland can be enhanced as a habitat for these insects by growing annual nectar- and pollen-producing herbaceous plants for them in noncropped areas such as set-aside and field margins, and by providing additional suitable nesting substrate zones $[60,61]$. This may work better for polylectic species in particular. For example, Cane et al. [62] found that habitat fragmentation reduced the abundance and richness of oligolectic but not polylectic bees, suggesting higher extirpation rates in the former.

For what concerns L. malachurum in Central Italy, the creation of patches of ground (following, e.g., the method described in [61]), characterized by the needed features mentioned above, in proximity of target plant species populations such as chicory and daisy, may increase the fitness of such economically valuable species; presence of other mixed species of plants, mainly composites, may be readily used by the bees during periods of low blooming of the target species. L. malachurum is very widespread in the Park (Polidori et al., unpublished data) and thus probably possesses good dispersion and colonization capacities.

\section{Acknowledgments}

Thanks are due to the Maremma Regional Park offices for support and permit to perform the field work. C. Ravazzi kindly has permitted the use of his laboratory for the palynological analysis, and F. Andrietti gave useful suggestions on an early draft of the manuscript. The authors are indebted to R. Henry L. Disney, which kindly revised the English. This work was supported by a 3-year grant FIRB from the Italian Ministry of University (RBAU019H94-0012001).

\section{References}

[1] S. A. Corbet, I. H. Williams, J. L. Osborne, et al., "Bees and the pollination of crops and wild flowers in the European Community," Bee World, vol. 72, pp. 47-59, 1991.

[2] K. S. Delaplane and D. F. Mayer, Crop Pollination by Bees, CABI Publishing, Wallingford, UK, 2000.

[3] T. Tscharntke, A. M. Klein, A. Kruess, I. Steffan-Dewenter, and C. Thies, "Landscape perspectives on agricultural intensification and biodiversity-ecosystem service management," Ecology Letters, vol. 8, no. 8, pp. 857-874, 2005.
[4] J. E. Losey and M. Vaughan, "The economic value of ecological services provided by insects," BioScience, vol. 56, no. 4, pp. 311-323, 2006.

[5] J. R. Krebs, J. D. Wilson, R. B. Bradbury, and G. M. Siriwardena, "The second silent spring?" Nature, vol. 400, no. 6745, pp. 611-612, 1999.

[6] C. Kremen, N. M. Williams, and R. W. Thorp, "Crop pollination from native bees at risk from agricultural intensification," Proceedings of the National Academy of Sciences of the United States of America, vol. 99, no. 26, pp. 16812-16816, 2002.

[7] A.-M. Klein, B. E. Vaissière, J. H. Cane, et al., "Importance of pollinators in changing landscapes for world crops," Proceedings of the Royal Society B, vol. 274, no. 1608, pp. 303313, 2007.

[8] A.-M. Klein, I. Steffan-Dewenter, and T. Tscharntke, "Fruit set of highland coffee increases with the diversity of pollinating bees," Proceedings of the Royal Society B, vol. 270, no. 1518, pp. 955-961, 2003.

[9] S. S. Greenleaf and C. Kremen, "Wild bee species increase tomato production and respond differently to surrounding land use in Northern California," Biological Conservation, vol. 133, no. 1, pp. 81-87, 2006.

[10] J. H. Cane, "Lifetime monetary value of individual pollinators: the bee Habropoda laboriosa at rabbiteye blueberry (Vaccinium ashei Reade)," Acta Horticultura, vol. 446, pp. 67-70, 1997.

[11] P. Westrich, "Habitat requirements of central European bees and the problems of partial habitats," in The Conservation of Bees, A. Matheson, S. L. Buchmann, C. O’Toole, P. Westrich, and I. H. Williams, Eds., pp. 1-16, Academic Press, London, UK, 1996.

[12] K. Walther-Hellwig and R. Frankl, "Foraging habitats and foraging distances of bumblebees, Bombus spp. (Hym., Apidae), in an agricultural landscape," Journal of Applied Entomology, vol. 124, no. 7-8, pp. 299-306, 2000.

[13] C. Carvell, W. R. Meek, R. F. Pywell, and M. Nowakowski, "The response of foraging bumblebees to successional change in newly created arable field margins," Biological Conservation, vol. 118, no. 3, pp. 327-339, 2004.

[14] D. Goulson, M. E. Hanley, B. Darvill, J. S. Ellis, and M. E. Knight, "Causes of rarity in bumblebees," Biological Conservation, vol. 122, no. 1, pp. 1-8, 2005.

[15] S. G. Potts, B. Vulliamy, S. Roberts, et al., "Role of nesting resources in organising diverse bee communities in a Mediterranean landscape," Ecological Entomology, vol. 30, no. 1, pp. 78-85, 2005.

[16] M. Beil, H. Horn, and A. Schwabe, "Analysis of pollen loads in a wild bee community (Hymenoptera: Apidae)—a method for elucidating habitat use and foraging distances," Apidologie, vol. 39, no. 4, pp. 456-467, 2008.

[17] D. Goulson, "Conserving wild bees for crop pollination," Food, Agriculture and Environment, vol. 1, pp. 142-144, 2003.

[18] I. Steffan-Dewenter, A. M. Klein, T. Alfert, V. Gaebele, and T. Tscharntke, "Bee diversity and plant-pollinator interactions in fragmented landscapes," in Specialization and Generalization in Plant-Pollinator Interactions, N. M. Waser and J. Ollerton, Eds., pp. 387-408, Chicago Press, Chicago, Ill, USA, 2006.

[19] C. M. Herrera, "Variation in mutualisms: the spatiotemporal mosaic of a pollinator assemblage," Biological Journal of the Linnean Society, vol. 35, no. 2, pp. 95-125, 1988.

[20] A. Dafni and C. O’Toole, "Pollination syndromes in the Mediterranean: generalisations and peculiarities," in Plantanimal Interactions in Mediterranean Type Ecosystems, M. Arianoutsou and R. H. Groves, Eds., pp. 125-135, Kluwer Academic Publishers, Dordrecht, The Netherlands, 1994. 
[21] J. Bosch, J. Retana, and X. Cerdà, "Flowering phenology, floral traits and pollinator composition in a herbaceous Mediterranean plant community," Oecologia, vol. 109, no. 4, pp. 583-591, 1997.

[22] J. Bosch, "Floral biology and pollinators of three co-occurring Cistus species (Cistaceae)," Botanical Journal of the Linnean Society, vol. 109, no. 1, pp. 39-55, 1992.

[23] P. Westrich, Die Wildbienen Baden-Württembergs, Ulmer, Stuttgart, Germany, 1989.

[24] A. R. Moldenke, "Host-plant coevolution and the diversity of bees in relation to the flora of North America," Phytologia, vol. 43, pp. 357-419, 1979.

[25] J. H. Cane, "Soils of ground-nesting bees (Hymenoptera: Apoidea): texture, moisture, cell depth and climate," Journal of the Kansas Entomological Society, vol. 64, pp. 406-413, 1991.

[26] C. T. Wuellner, "Nest site preference and success in a gregarious, ground-nesting bee Dieuomia triangulifera," Ecological Entomology, vol. 24, pp. 471-479, 1999.

[27] S. G. Potts and P. Willmer, "Abiotic and biotic factors influencing nest-site selection by Halictus rubicundus, a groundnesting halictine bee," Ecological Entomology, vol. 22, no. 3, pp. 319-328, 1997.

[28] A. Soro, M. Ayasse, M. U. Zobel, and R. J. Paxton, "Complex sociogenetic organization and the origin of unrelated workers in a eusocial sweat bee, Lasioglossum malachurum," Insectes Sociaux, vol. 56, no. 1, pp. 55-63, 2009.

[29] G. Knerer, "The biology and social behaviour of Evylaeus malachurus (K.) (Hymenoptera; Halictidae) in different climatic regions of Europe," Zoologische Jahrbucher: Abteilung fur Systematik, Okologie und Geographie der Tiere, vol. 119, no. 2, pp. 261-290, 1992.

[30] L. M. Wyman and M. H. Richards, "Colony social organization of Lasioglossum malachurum Kirby (Hymenoptera, Halictidae) in southern Greece," Insectes Sociaux, vol. 50, no. 3, pp. 201-211, 2003.

[31] O. Mitesser, N. Weissel, E. Strohm, and H.-J. Poethke, "The evolution of activity breaks in the nest cycle of annual eusocial bees: a model of delayed exponential growth," BMC Evolutionary Biology, vol. 6, article 45, 2006.

[32] N. Weissel, O. Mitesser, J. Liebig, H.-J. Poethke, and E. Strohm, "The influence of soil tempertaure on the nesting cycle of the halictid bee Lasioglossum malachurum," Insectes Sociaux, vol. 53, pp. 390-398, 2006.

[33] C. Polidori, L. Borruso, R. Boesi, and F. Andrietti, "Segregation of temporal and spatial distribution between kleptoparasites and parasitoids of the eusocial sweat bee, Lasioglossum malachurum (Hymenoptera: Halictidae, Mutillidae)," Entomological Science, vol. 12, no. 2, pp. 116-129, 2009.

[34] S. S. Greenleaf, N. M. Williams, R. Winfree, and C. Kremen, "Bee foraging ranges and their relationship to body size," Oecologia, vol. 153, no. 3, pp. 589-596, 2007.

[35] A. Gathmann and T. Tscharntke, "Foraging ranges of solitary bees," Journal of Animal Ecology, vol. 71, no. 5, pp. 757-764, 2002.

[36] G. Erdtman, Pollen Morphology and Plant Taxonomy, Angiosperms (An Introduction of Palynology), Hanerphtb, London, UK, Revised edition, 1966.

[37] P. D. Moore, J. A. Webb, and M. A. Collinson, Pollen Analysis, Blackwell Scientific, Oxford, UK, 2nd edition, 1991.

[38] M. Reille, Pollen et spores d'Europe et d'Afrique du nord, Laboratoire de botanique historique et palynologie, URA CNRS, Marseille, France, 1992.
[39] M. Reille, Pollen et spores d'Europe et d'Afrique du nord Supplement 1, Laboratoire de botanique historique et palynologie, URA CNRS, Marseille, France, 1995.

[40] M. Reille, Pollen et spores d'Europe et d'Afrique du nord Supplement 2, Laboratoire de botanique historique et palynologie, URA CNRS, Marseille, France, 1998.

[41] W. Punt, The Northwest European Pollen Flora. I, Elsevier, Amsterdan, The Netherlands, 1976.

[42] W. Punt and C. G. S. Clarke, The Northwest European Pollen Flora. II, Elsevier, Amsterdan, The Netherlands, 1980.

[43] W. Punt and C. G. S. Clarke, The Northwest European Pollen Flora. III, Elsevier, Amsterdan, The Netherlands, 1981.

[44] W. Punt and C. G. S. Clarke, The Northwest European Pollen Flora. IV, Elsevier, Amsterdan, The Netherlands, 1984.

[45] W. Punt, S. Blackmore, and C. G. S. Clarke, The Northwest European Pollen Flora. V, Elsevier, Amsterdan, The Netherlands, 1988.

[46] W. Punt, S. Blackmore, and C. G. S. Clarke, The Northwest European Pollen Flora. VI, Elsevier, Amsterdan, The Netherlands, 1991.

[47] W. Punt, S. Blackmore, and P. P. Hoen, Eds., The Northwest European Pollen Flora. VII, Elsevier, Amsterdan, The Netherlands, 1995.

[48] P. Westrich and K. Schmidt, "Methoden und Anwendungsgebiete der Pollenanalyse bei Wildbienen (Hymenoptera, Apidae)," Linzer Biologie Beiträge, vol. 18, pp. 341-360, 1986.

[49] S. J. Gale and P. G. Hoare, Quaternary Sediments, Belhaven Press, London, UK, 1991.

[50] Ministero delle risorse agricole and alimentari e forestali, Osservatorio Nazionale Podologico per la qualità del suolo. Metodi ufficiali per l'analisi chimica del suolo, con commenti ed interpretazioni, ISMEA, Roma, Italy, 1994.

[51] A. V. Lopatin and T. F. Tregub, "Studying trophic relationships of the bee Seladonia subaurata (Rossi) (Hymenoptera, Halictidae) by analyzing pollen from nest cells," Russian Journal of Ecology, vol. 35, no. 4, pp. 259-262, 2004.

[52] R. E. Dolphin, The ecological life history of Halictus (Seladonia) confusus Smith (Hymenoptera, Halictidae), Ph.D. dissertation, Purdue University, 1966.

[53] C. D. Michener and A. Wille, "The bionomics of a primitively social bee, Lasioglossum inconspicuum," University of Kansas Science Bulletin, vol. 42, pp. 1123-1202, 1961.

[54] J. B. Free, “The flower constancy of bumble bees," Journal of Animal Ecology, vol. 39, pp. 395-402, 1970.

[55] C. L. Gross, "Floral traits and pollinator constancy: foraging by native bees among three sympatric legumes," Australian Journal of Ecology, vol. 17, no. 1, pp. 67-74, 1992.

[56] S. D. Sipes and V. J. Tepedino, "Pollen-host specificity and evolutionary patterns of host switching in a clade of specialist bees (Apoidea: Diadasia)," Biological Journal of the Linnean Society, vol. 86, no. 4, pp. 487-505, 2005.

[57] C. D. Michener, The Bees of the World, Johns Hopkins University Press, Baltimore, Md, USA, 2007.

[58] D. P. Abrol, "Studies on abundance, diversity, behaviour and importance of native pollinators for crop production," The Korean Journal of Apiculture, vol. 4, pp. 25-40, 1989.

[59] C. Polidori, R. H. L. Disney, R. Boesi, and F. Andrietti, "Association of the scuttle fly Megaselia leucozona Schmitz (Diptera: Phoridae) with sweat bees (Hymenoptera: Halictidae), with a description of the male fly," Entomologica Fennica, vol. 16, no. 3, pp. 144-150, 2005. 
[60] N. L. Carreck and I. H. Williams, "Food for insect pollinators on farmland: insect visits to flowers of annual seed mixtures," Journal of Insect Conservation, vol. 6, no. 1, pp. 13-23, 2002.

[61] S. J. Gregory and I. R. Wright, "Creation of patches of open bare ground to enhance the habitat of ground-nesting bees and wasps," Conservation Evidence, vol. 2, pp. 139-141, 2005.

[62] J. H. Cane, R. L. Minckley, L. J. Kervin, T. H. Roulston, and N. M. Williams, "Complex responses within a desert bee guild (Hymenoptera: Apiformes) to urban habitat fragmentation," Ecological Applications, vol. 16, no. 2, pp. 632-644, 2006. 

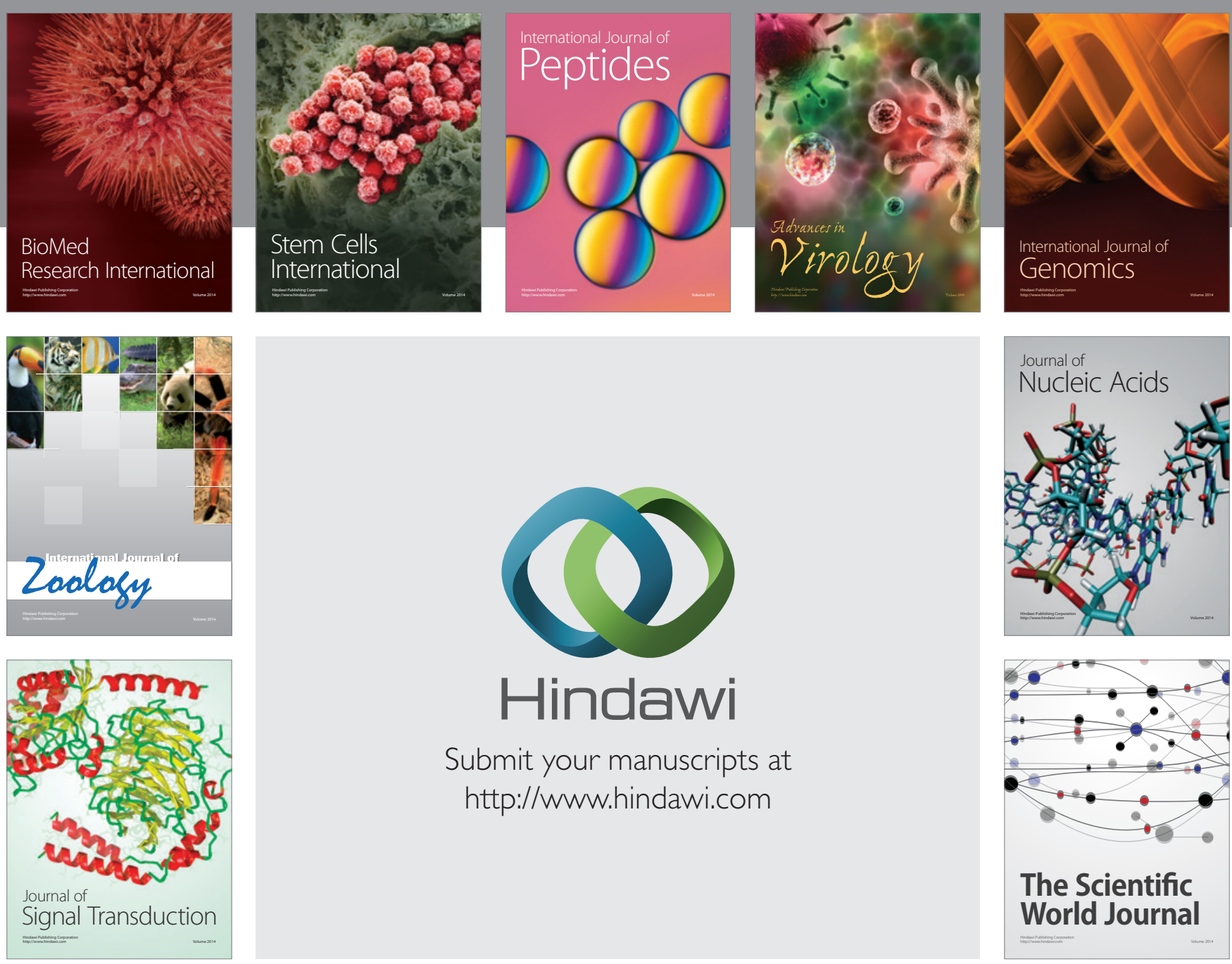

Submit your manuscripts at

http://www.hindawi.com
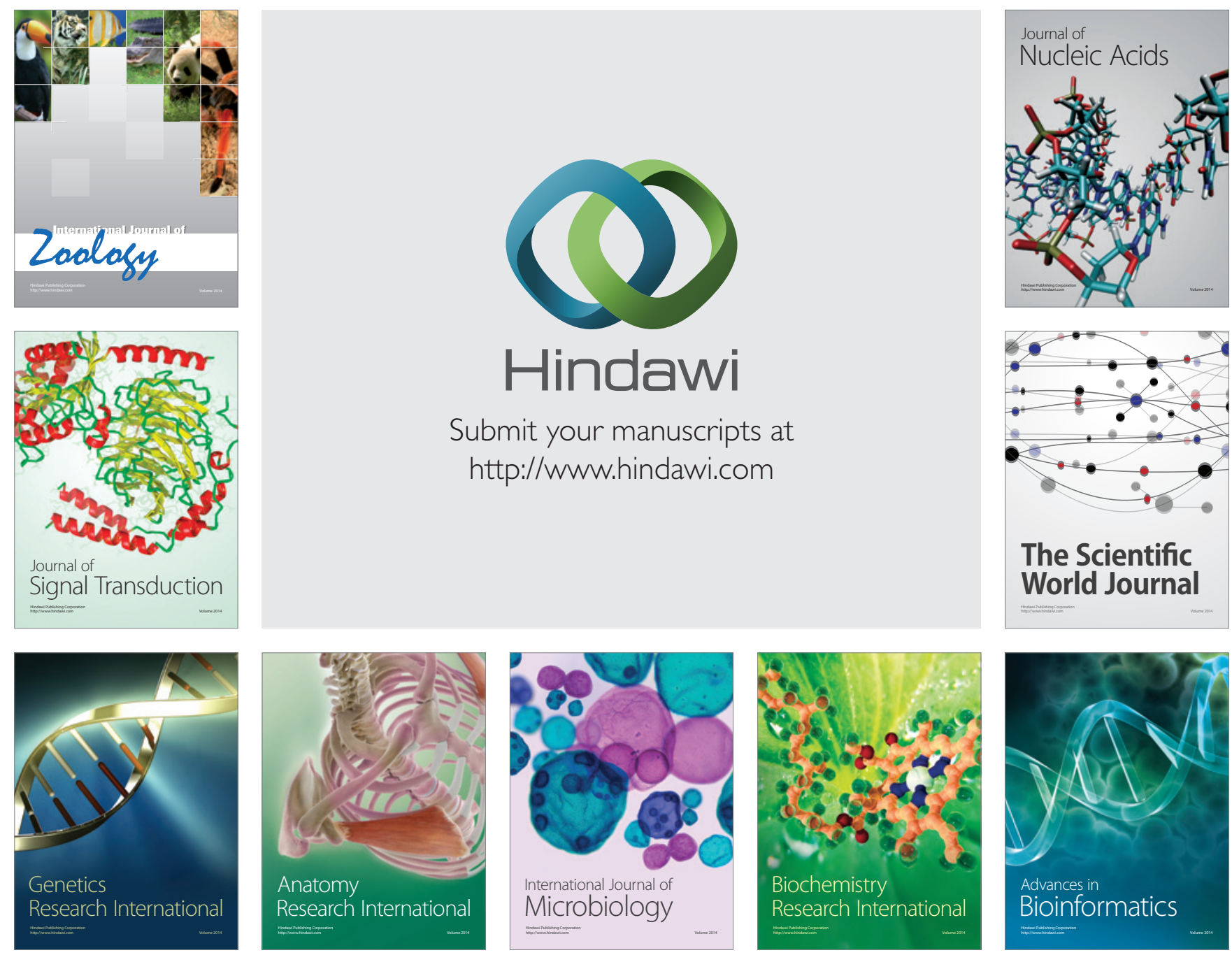

The Scientific World Journal
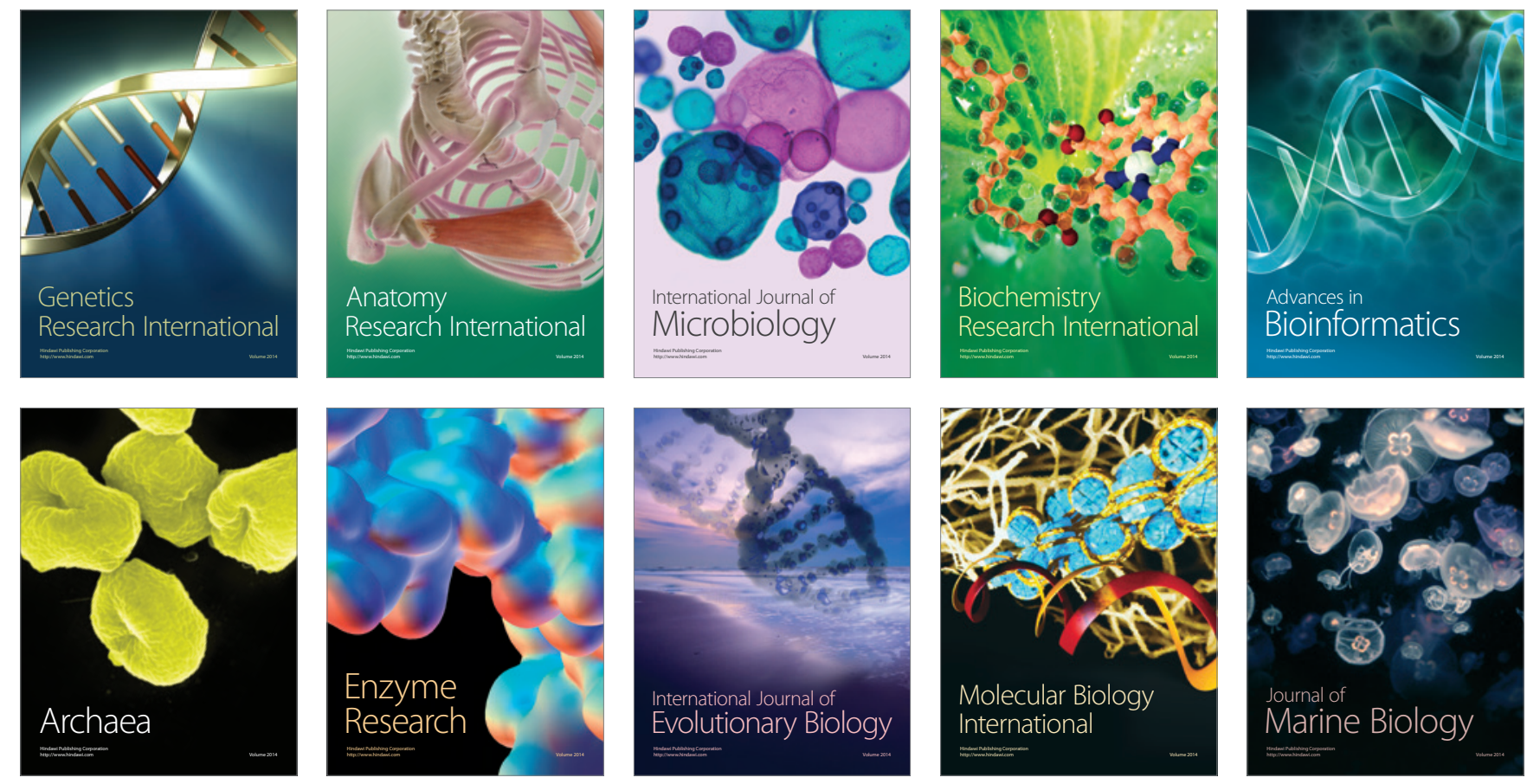